\title{
Comparison of Farmer's Agriculture Information Channels and Farming Practice in Tanzania
}

\author{
Dr. Peter Josephat (Corresponding Author) \\ Department of Statistics, University of Dodoma \\ P. O. Box 338, Dodoma, Tanzania
}

Mobile: 255787288998

Prof.Ahmed Ame

Department of Business Studies, University of Dodoma

P. O. Box 395, Dodoma, Tanzania

Mobile: 255658580212

Received: February 4, 2016 Accepted: February 24, 2016 Published: March 11, 2016

doi:10.5296/jas.v4i2.8994ＵRL: http://dx.doi.org/10.5296/jas.v4i2. 8994

\begin{abstract}
There are mixed empirical evidences on the effectiveness of Farmer Field School (FFS). The evidences on various studies vary because of the setting, evaluation methods and yardstick used. This paper aims to investigate the impact of District Agricultural Sector Investment Project (DASIP) on knowledge and productivity. The study was conducted in the area where (DASIP) operated. This covered five regions namely Kagera, Mwanza, Mara, Simiyu and Kigoma. Within those regions, the study focused on agro-ecological zone where corn was cultivated. The data was collected from 878 farmers out of 971, who were targeted. Among them, 359 were participant and 519 were non-participant farmers. This study employed a five-stage sampling technique. The findings show that the effects of DASIP on participating farmers are very little as they resemble non-participating farmers in terms of knowledge and farming practices. Despite that, non-participating farmers are 8.724 times the odds of corn yield not to increase compared to participating farmers. Based on findings, it may recommended that, agriculture programmes should run smoothly by providing technical and financial commitment to improve the performance of extension officers.
\end{abstract}

Keywords: Farmer Field School, DASIP, knowledge, productivity 


\section{Introduction}

The design of agricultural extension programmes in developing countries has been the subject of heated debate (Godtland et al., 2004). Guided by these debates, extension services have undergone several transformations in the past few decades (Godtland et al, 2004). The main transformation, until recently, was a shift from the transfer of technology approach to the training and visit. From that, a number of development agencies have promoted Farmer Field Schools (FFS) as a more potential effective approach to extend knowledge to farmers (Godtland et al, 2004).

The extension methods are effective means of communication to provide knowledge and skills, so that the learner may see, hear, and do the things conveyed by extension worker. FFS stimulate adult and youth male and female for action. FFS model aims to help farmers to discover and learn about the field ecology and integrated crop management. On the basis of this knowledge, farmers become independent, confident decision makers and experts in their own fields (Fliert and Vande-Fliert, 1993 as cited in Habib et al., 2007).

There are mixed empirical evidences of the effectiveness of FFS. The evidences on various studies vary because of setting, evaluation methods and the yardstick used to assess impact (Godtland et al., 2004). Yamazaki and Resosudarmo (2007) explain that there has been an intensive debate as to whether or not this kind of training has any significant impact. Most case studies report that the impact in terms of the farmer's ability to reduce the use or pesticides while increasing yields is significant. However, other studies such as that by Feder et al., (2004) show that using a household panel data set for Indonesia could not confirm that this is the case.

Although the FFS approach is a popular method, its long-term impacts remain unclear. There is limited or conflicting evidence of FFS on productivity and poverty, especially in East Africa (Davis et al., 2010). One of the biggest problems with many of the developments in FFS over the years has been the tendency to generalise and make recommendations for the farmers across large and highly heterogeneous areas.

The projects on farmer training in developing countries using the FFS approach are still widely implemented by donor organizations including the World Bank. Such projects are fiscally unsustainable (Quizon et al., 2001) and are not always improving farm performance (Feder et al., 2004) and have only limited diffusion effects (Rola et al., 2002; Praneetvatakul and Waibel, 2006).

The literature shows that, the effectiveness of transferring of knowledge to farmers is not universal. In Tanzania for example, the District Agricultural Sector Investment Project (DASIP) was a government agriculture intervention programme which operated in five regions (2006 - 2013). In the intervention area, there are factors which affect both knowledge dissemination and productivity because of different climate conditions, soil fertility, capacities of agricultural official extensions, levels of education of farmers and their capacities of adoption and innovation, to mention few. 


\section{Ml Macrothink}

Journal of Agricultural Studies

ISSN 2166-0379

2016, Vol. 4, No. 2

The report of implementation of DASIP was prepared every year and shows positive impact. The maize productivity among farmers who adopted improved farming practices increased more than four times in the project area from an average of 1 ton to 4.2 tons per hectare. Moreover, the report shows that the farmers were able to afford three meals a day and had a surplus for sale. Unfortunately, the methodology used for analysis is unclear. Moreover, few studies have been conducted which analyzed data by agro-ecological zones. This paper aims to investigate the impact of DASIP on knowledge and productivity to fill the gaps.

\section{Material and Methods}

\subsection{Area of Study}

The study was conducted in the area where DASIP operated. It covered five regions namely Kagera, Mwanza, Mara, Simiyu and Kigoma. Within the regions, the study focused on agro-ecological zone where the corn was cultivated.

\subsection{Population and Sample}

The target population of this study was people who were involved in the DASIP intervention area. It included corn farmers and DASIP officers. Both DASIP participant and non-participant farmers were included in the study. Participant farmers are those who were engaged in DASIP while non-participating farmers are farmers who were not engaged in DASIP. A sampling unit was individual farmers who were relevant for the study at hand. The data was collected from 878 farmers out of 971 who were targeted. Among them, 359 were participating whereas 519 were non-participating farmers.

\subsection{Sampling Techniques}

The study employed a five-stage sampling technique. Firstly, the agro-ecological zones were selected, and then districts, villages, Participatory Farmers Group (PFG) and farmers. The regions were not sampled as the study collected the data from all regions. One of the reasons for not sampling regions was that they differed in terms of agro-ecological zone. Agro-ecological zones involved in this study are described in Table 1. The participating and non-participating farmers were purposively selected in the study.

Table 1. Distribution of Sampled Districts per Agro-ecological Zone

\begin{tabular}{|l|l|l|}
\hline Region & Agro-ecological zone (s) & District \\
\hline \multirow{4}{*}{ Kagera } & Plateau area & Bukoba rural \\
\cline { 2 - 3 } & Lowlands & Biharamulo \\
\hline \multirow{4}{*}{ Mara } & Lake Tanganyika shore & Kigoma rural \\
\cline { 2 - 3 } & Miombo & \multirow{2}{*}{ Kasulu } \\
\cline { 2 - 3 } & Intermediate & Butiama \\
\hline \multirow{3}{*}{ Mwanza } & Midlands & Tarime \\
\cline { 2 - 3 } Simiyu & Tarime highlands & Misungwi \\
\hline & Zone II & Kwimba \\
\cline { 2 - 3 } & Zone V & Bariadi \\
\hline
\end{tabular}




\subsection{Data Collection Methods}

The study used self-administered delivered questionnaire and semi-structured interviews to collect the primary data. The use of self-administered delivered and collection questionnaire was preferred in this study because it permitted direct contact with potential respondents who induced the greater proportion of respondents to complete the questionnaire taking into account that the study had large coverage (five regions and nine districts). In order to control the bias, the study used same questionnaire for both control and treatment units to collect the data.

The interview method was adopted in order to explore the views and experiences of DASIP officers on farm practice of farmers in the intervention areas. This method was used because of its flexibility compared to structured interviews as it allowed asking detailed questions which provided the rich data from respondents.

The secondary data in this study involved the information related to non-experimental methods used to evaluate the impact of the programmes particularly DASIP. The information was obtained from various previous studies, journals, books and DASIP reports.

\subsection{Data Analysis}

Both descriptive and inferential statistics were used during the data analysis. The analysis about the information channel, farming knowledge and practices was done using the descriptive statistics such as percentages and graphs because by nature, the response to the questions was non-numeric. The inferential statistics such as t test and logit model were used during the analysis of the relationship between the source of information and corn yields.

\section{Results and Discussion}

The response rate of the study was $90.4 \%$. Burns et al. (2008) argue that the response rate of at least $70 \%$ is needed for external validity; however, the response rate between $60 \%$ and $70 \%$ may be acceptable. The response rate of this study is acceptable as it is relatively higher compared to recommended level. It is suggested that the precision of the parameter estimates for this study was increased and the selection bias was reduced. There is no clear rule of thumb on the sample size required for the control and treatment groups.

\subsection{Information Channel}

According to Csótó (2010), information has a central role in modern way of living and agriculture is no exception. In order for a farmer to be successful, he/she requires gaining, processing, using and evaluating a huge amount of information. This information includes policy, markets, new methods, etc. Because of its importance, the study sought to know the channels of information the farmers had. The information channels were inspected in order to see to what extent DASIP had played a role in giving agricultural information to participating farmers in the study area, taking into account that the dissemination of information and modern knowledge on agriculture in rural areas is limited (see Abosede et al., 2014). 


\subsubsection{Access of Information}

Access to information was examined by using two components namely agronomic practices and technical issues. The agronomic practices and technical issues are vital in agriculture as they include the farm management starting with land preparation, seeding, harvesting and storage. The improper information and practice of agronomic affect yields (see Akowuah et al., 2012 and Sher, 2013).

The access to information on agronomic practices was measured on seven items namely the land preparation, fertilizer use and crop residue management, pesticides, best varieties and seed selection, planting time, method and spacing, weeding, harvesting (time and techniques). The results are presented in Table 2. From the Table, it can be revealed that most of the farmers (both control and treatment) got information by their own experience. The rate of accessing information from DASIP officers was low. The participating farmers had slight higher access of information from DASIP compared to non-participating farmers. For example, land preparation; while only $0.4 \%$ of non-participating farmers accessed information from DASIP officers, it is $7.3 \%$ for participating farmers. The access to information on fertilizer use and crop residue management from DASIP officers is $1.2 \%$ for non-participating farmers while it is $14.8 \%$ for participating farmers. This result is experienced in all the rest of the results in Table 2. The majority of non-participating farmers were able to get information from DASIP officers because most of the DASIP extension officers worked also as district agricultural officers. When DASIP started, some of the district agricultural officers were tasked to coordinate and oversee DASIP in the districts.

Another type of source of information examined is technical issues. Eight items namely the improved varieties, insects and pests management practices, diseases management practices, fertilizer type, timing and method of application, pesticide and application, weed control, harvest and transportation, storage (techniques and chemicals and their application) were used . Sources of information on technical issues are presented in Table 3.

Like agronomic practices, all eight items on technical issues were from own experience for non-participating farmers. The situation is quite different to participating farmers as most of the information was obtained from Village/District Agricultural Officers. The information obtained from Village/District Agricultural Officers by participating farmers on improved varieties accounted for $41.8 \%$, insects and pests management practices accounted for $42.2 \%$ while diseases management practices accounted for $40.8 \%$. The results for the rest of the items with percentages in brackets are as follows; the fertilizer type, timing and method of application (46.5\%) and pesticide and application (42.7\%). These are items for which most of information was obtained from the agricultural officers apart from DASIP officers. For the remaining three items namely weed control (48.1\%), harvest and transportation $(68.4 \%)$, storage (techniques and chemicals and their application) (56.8\%), the information was obtained by farmers' own experiences.

The information from DASIP officers is the third most mentioned source of information in addition to agricultural officers and own experience. The least information obtained from DASIP officers included harvest and transportation (7.0\%), storage (techniques and 
chemicals and their application) (12.1\%) and weed control (13.4\%).

Table 2. Source of Information on Agronomic Practices

\begin{tabular}{|c|c|c|c|c|c|c|c|c|c|c|c|c|c|}
\hline \multirow[b]{2}{*}{ Information } & \multirow[b]{2}{*}{$\begin{array}{l}\text { ?े } \\
\text { ثं }\end{array}$} & \multicolumn{12}{|l|}{$0^{\circ}$} \\
\hline & & 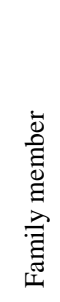 & $\begin{array}{l}\vdots \\
0 \\
00 \\
\frac{0}{00} \\
\overline{0}\end{array}$ & 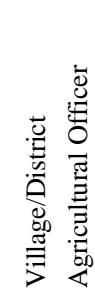 & 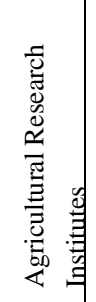 & 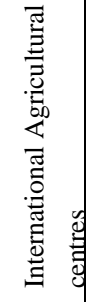 & 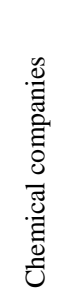 & 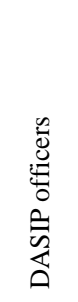 & 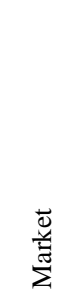 & 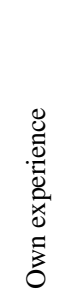 & 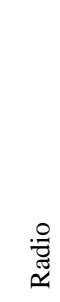 & $\frac{0}{\frac{0}{0}}$ & : \\
\hline \multirow{2}{*}{$\begin{array}{l}\text { Land } \\
\text { preparation }\end{array}$} & Control & 10.6 & 1.2 & 2.0 & 0.2 & - & - & 0.4 & 0.2 & 84.3 & 1 & - & 0.2 \\
\hline & Treatment & 7.9 & 0.3 & 13.6 & 0.6 & - & - & 7.3 & - & 70.3 & - & - & - \\
\hline \multirow{2}{*}{$\begin{array}{l}\text { Fertilizer use } \\
\text { and crop residue } \\
\text { management }\end{array}$} & Control & 5.7 & 1.6 & 17 & 1 & - & 0.4 & 1.2 & 0.2 & 70.2 & 1.4 & - & 1.0 \\
\hline & Treatment & 3.7 & 1.1 & 36.4 & 0.3 & - & 0.3 & 14.8 & & 42.6 & 0.9 & - & - \\
\hline \multirow[t]{2}{*}{ Pesticides } & Control & 5.2 & 1.8 & 18.0 & 1.8 & 0.5 & 3.6 & 0.7 & 1.1 & 60.5 & 5.7 & 0. & 0.9 \\
\hline & Treatment & 3.2 & 0.6 & 35.4 & 1 & 0.6 & 5.5 & 20.5 & & 26.9 & 6.2 & - & - \\
\hline \multirow{2}{*}{$\begin{array}{l}\text { Best varieties } \\
\text { and seed } \\
\text { selection }\end{array}$} & Control & 5.1 & 1.8 & 20.4 & 2 & 0.8 & 1.4 & 1.6 & 3.6 & 59.8 & 2.8 & & 0.6 \\
\hline & Treatment & 1.7 & 2 & 42.7 & 2.8 & 0.3 & 2.3 & 16.0 & 0.6 & 27.9 & 3.4 & & 0.3 \\
\hline \multirow{2}{*}{$\begin{array}{l}\text { Planting time, } \\
\text { method, and } \\
\text { spacing }\end{array}$} & Control & 4.8 & 0.8 & 10.1 & 0.8 & 0.4 & 0.2 & 0.8 & & 80.7 & 0.4 & 0.4 & 0.6 \\
\hline & Treatment & 4.3 & & 23.6 & 0.9 & & & 11.7 & 0.3 & 58.4 & & & 0.9 \\
\hline \multirow[t]{2}{*}{ Weeding } & Control & 10.8 & & 1.2 & 0.4 & 0.2 & & & & 86.2 & 0.2 & & 1 \\
\hline & Treatment & 14.3 & 0.3 & 9.0 & & & & 5.3 & & 71.1 & & & \\
\hline \multirow{2}{*}{$\begin{array}{l}\text { Harvesting (time } \\
\text { and techniques) }\end{array}$} & Control & 7.7 & 0.6 & 3.4 & 0.8 & 0.2 & & 0.8 & & 85.4 & 0.2 & & 0.8 \\
\hline & Treatment & 10.9 & & 14.0 & 0.6 & & & 5.7 & & 68.5 & 0.3 & & \\
\hline
\end{tabular}

Source: Field Data (2013) 


\section{MInstitute Macrothink $_{\text {Int }}$}

Table 3. Source of Information on Technical Issues

\begin{tabular}{|c|c|c|c|c|c|c|c|c|c|c|c|c|c|}
\hline \multirow[b]{2}{*}{$\begin{array}{l}\text { Source of } \\
\text { Information }\end{array}$} & \multirow[b]{2}{*}{ 节 } & \multicolumn{12}{|l|}{$\delta^{\circ}$} \\
\hline & & 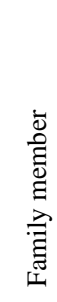 & $\begin{array}{l}3 \\
0 \\
\frac{0}{0} \\
\frac{000}{0} \\
z\end{array}$ & 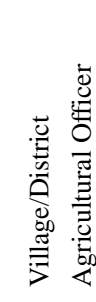 & 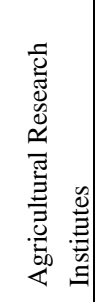 & 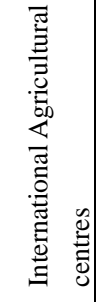 & 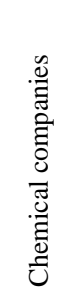 & 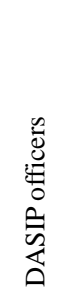 & 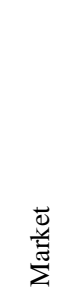 & 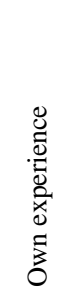 & 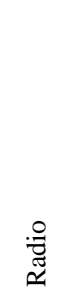 & $\frac{0}{\frac{0}{3}}$ & 芷 \\
\hline \multirow[t]{2}{*}{ Improved varieties } & Control & 2.8 & 2.3 & 28.6 & 3.2 & 0.2 & 1.9 & 1.3 & 2.3 & 51.4 & 5.3 & 0.2 & 0.4 \\
\hline & Treatment & 0.3 & 2.1 & 41.8 & 2.6 & - & 3.2 & 23.2 & - & 20.3 & 6.5 & - & - \\
\hline \multirow{2}{*}{$\begin{array}{l}\text { Insects and pests } \\
\text { management } \\
\text { practices }\end{array}$} & Control & 3.7 & 1.1 & 28.3 & 1.3 & 0.7 & 2.4 & 1.1 & 0.9 & 53.9 & 5.9 & 0.2 & 0.7 \\
\hline & Treatment & 0.9 & 0.9 & 42.2 & 1.2 & 1.2 & 4.1 & 20.3 & - & 26.7 & 2.6 & - & - \\
\hline \multirow{2}{*}{$\begin{array}{l}\text { Diseases } \\
\text { management } \\
\text { practices }\end{array}$} & Control & 4.1 & 1.3 & 26.5 & 3.3 & 0.2 & 2.4 & 0.9 & 0.2 & 56.3 & 4.1 & - & 0.7 \\
\hline & Treatment & 2.3 & - & 40.8 & 0.9 & - & 4.1 & 27.1 & - & 23 & 1.5 & - & 0.3 \\
\hline \multirow{2}{*}{$\begin{array}{l}\text { Fertilizer type, } \\
\text { timing and method } \\
\text { of application }\end{array}$} & Control & 3.4 & 1.7 & 24.8 & 1.7 & 0.6 & 0.4 & 1.9 & 0.8 & 62.1 & 1.9 & 0.2 & 0.4 \\
\hline & Treatment & 1.2 & 1.2 & 46.5 & 1.2 & - & 1.2 & 21.3 & - & 26.6 & 0.3 & - & 0.6 \\
\hline \multirow{2}{*}{$\begin{array}{l}\text { Pesticide and } \\
\text { application }\end{array}$} & Control & 5.4 & 1.3 & 22.5 & 1.6 & 1.3 & 4 & 1.8 & 0.9 & 56.3 & 4.7 & 0.2 & - \\
\hline & Treatment & 0.3 & 0.9 & 42.7 & 1.9 & - & 7.9 & 20.3 & - & 22.8 & 3.2 & - & - \\
\hline \multirow[t]{2}{*}{ Weed control } & Control & 6.1 & 0.6 & 9.1 & 0.4 & 0.2 & 1.3 & 0.8 & - & 78.3 & 2.1 & 0.2 & 0.8 \\
\hline & Treatment & 3.1 & 0.6 & 29.4 & 1.3 & - & 1.3 & 13.4 & 0.3 & 48.1 & 2.5 & - & - \\
\hline \multirow{2}{*}{$\begin{array}{l}\text { Harvest and } \\
\text { transportation }\end{array}$} & Control & 9.0 & 0.2 & 3.8 & 0.2 & 0.2 & 0.4 & 0.2 & 0.8 & 84.6 & 0.2 & 0.2 & 0.2 \\
\hline & Treatment & 12 & 0.3 & 11.7 & - & 0.3 & - & 7.0 & - & 68.4 & 0.3 & - & - \\
\hline \multirow{2}{*}{$\begin{array}{l}\text { Storage (techniques } \\
\text { and chemicals and } \\
\text { their application) }\end{array}$} & Control & 5.7 & 0.8 & 13.5 & 1.0 & 0.2 & 1.4 & 1.4 & 0.4 & 73.6 & 1.6 & - & 0.2 \\
\hline & Treatment & 6.8 & - & 21.0 & - & - & 2.7 & 12.1 & - & 56.8 & 0.6 & - & - \\
\hline
\end{tabular}

Source: Field Data (2013)

The results on agricultural information channel are not very far from what Godtland et al. (2004) finds. While this study finds out that most of the information was from own experiences, Godtland et al. (2004) finds out that potato farming information was obtained from family members while information on new technologies such as new varieties, pesticides and fungicides was obtained from neighbours in the community. Since the main source of information was from own experience, these results indicate that the effects of DASIP on agricultural information was ineffective. The results suggest further that more effort was to be done by DASIP. The low percentage on market, radio and television sources of information could be because the study was conducted in rural areas where the usage of television and radio was limited.

Mtega and Ronald (2013) conducted a meta-analysis on rural information and 
communication services in Tanzania and found out that most rural areas in Tanzania had inadequate information services. They pointed out that the majority of rural communities would access agricultural information through radio, neighbours and friends, village leaders, agricultural extension officers, personal experience, family and friends, and farmer groups. The minority of farmers use Television (TV) sets, books, agricultural shows, internet, posters and leaflets, and notice boards. Despite the mentioned sources of information, the factors which limit access to information included socio-economic and demographic profiles such as the level of education and income. Additionally, there was late delivery of information services, irrelevant information provided, unaffordable costs of information services and high level of illiteracy. Other information constraints were identified to be poor and unreliable infrastructure, irrelevant time of broadcast of radio/TV programmes, use of difficult languages when repackaging information, lack of time to access information and geographical isolation.

Naveed and Anwar (2013) conducted a study on agricultural information needs of Pakistan farmers and found out that farmers mainly depended on interpersonal relationships in meeting their information needs. The role of mass media and printed materials as sources of information was found to be very low. Lack of timely access, low level of education and language barrier were the main problems that these farmers faced while getting the required information. According to Bello and Obinne (2012), one major constraint in information dissemination was the limited number of trained extension workers.

A study on agricultural information sources used by farmers in Imo State, Nigeria which was conducted by Opara (2008) finds out that $88.1 \%$ of the farmers indicated agricultural extension agents as their source of information, $71.2 \%$ indicated fellow farmers, $63.2 \%$ indicated radio, $43.3 \%$ indicated television, etc. Moreover, it was found that the majority $(70.0 \%)$ of farmers preferred the extension agent to the other media (radio 28.4\%, friends and relatives $27.2 \%$, television $19.1 \%$, etc.). Daudu et al. (2009) find out that most $(61.67 \%)$ of the farmers preferred extension agents as their source of information while the least $(6.17 \%)$ source was libraries. The major constraint indicated by farmers in sourcing information was financial problem.

The study conducted by Adhigurua et al. (2009) on agricultural information flow finds out that $40 \%$ of farm households would access information from one or the other source. Most of the farmers obtained information from fellow progressive farmers followed by input from leaders and mass media. The public extension system was found to be accessed by only $5.7 \%$ households. About $4.8 \%$ of the small farmers accessed public extension workers as compared to $12.4 \%$ large farmers. Naveed et al. (2012) finds out that the information sought by Pakistani farmers relied very much on interpersonal relationships with friends, relatives, fellow or progressive farmers, and neighbours for obtaining agricultural information.

\subsubsection{Type of Information Sought by Farmers}

The study was also interested to know which type of information was normally sought by farmers. Several types of information sought by farmers are presented in Table 4. It can be revealed that the most sought information for both non-participating and participating farmers 
was proper time for land preparation, planting time, methods, spacing, weeding and harvesting compared to other pieces of information as it stood at $51 \%$ for participants and $55.1 \%$ for non-participants.

Table 4. Type of Information Farmers Seek

\begin{tabular}{|c|c|c|c|c|}
\hline \multirow[t]{2}{*}{ Information } & \multicolumn{2}{|c|}{ Participating farmers } & \multicolumn{2}{|c|}{$\begin{array}{c}\text { Non-participating } \\
\text { farmers }\end{array}$} \\
\hline & $\mathbf{n}$ & $\%$ & $\mathbf{n}$ & $\%$ \\
\hline Climatic/Weather conditions & 161 & 31.8 & 125 & 35.1 \\
\hline $\begin{array}{l}\text { Proper time for land preparation, planting } \\
\text { time, methods, spacing, weeding and } \\
\text { harvesting }\end{array}$ & 258 & 51.0 & 196 & 55.1 \\
\hline New varieties & 46 & 9.1 & 26 & 7.3 \\
\hline $\begin{array}{l}\text { Fertilizer type, timing and method of } \\
\text { application }\end{array}$ & 118 & 23.3 & 100 & 28.1 \\
\hline Diseases and management practices & 95 & 18.8 & 57 & 16.0 \\
\hline Pesticides and their application & 68 & 13.4 & 23 & 6.5 \\
\hline Total & 746 & 147.4 & 527 & 148.0 \\
\hline
\end{tabular}

Source: Field Data (2013)

In order to ensure long term success of the plantation, it is necessary to prepare the land so as to provide the required soil conditions. The information about planting time is necessary in order to allow sufficient time for adaptation or understanding the planting season of a crop. The information about the methods to be applied and time for weeding are necessary for crop development and productivity. Spacing is necessary in order to allow the sufficient sunlight for crops, working space within the plantation and for root or crop development.

The second most sought information was weather condition as it accounted for $31.8 \%$ of the participating and $35.1 \%$ for non-participating farmers. The agricultural activities are very sensitive to climate and weather conditions. In order to increase productivity and earn profit, the weather condition should be taken into account. The agrometeorological information also known as climatological data is essential in planning agricultural production. This is a very crucial information for a farmer to know. Mbilinyi et al. (2013) argue that the climatic change affects the small scale subsistence farmers in terms of productivity, food security and family income. The crop farming and livestock keeping had been affected negatively by climatic change. The increase in the frequency of extreme events such as drought and flooding has reduced soil fertility and yields from crop production and livestock keeping. In their study, Naveed and Anwar (2013) find out that the information needed was centred on soil preparation, seeds, taking care of crops, harvesting activities, and animal husbandry. The climatic conditions information was sought by farmers since it helped them to handle the situation.

The fertilizer type, timing and method of application were the third type of information sought by farmers in the study area. The information was sought by $23.3 \%$ of the participating and $28.1 \%$ of the non-participating farmers. The fertilizer plays a major role in 
the growth of the crop and quality of product. An application rate of fertilizer depends mainly on soil fertility. This suggests that the growth of crops does not only require the fertilizer but rather the fertilizer which suits the environment of an area. There are mainly two fertilizer sources namely the commercial and organic sources. The commercial sources are characterised by high analysis fertilizers. High analysis means that the fertilizer contains a larger percentage of a given nutrient. The organic sources are low analysis i.e. contain a smaller percentage of a given nutrient. The application of fertilizer, requires knowledge for instance, the commercial fertilizers are used in lesser amounts than organic sources because of larger percentage of nutrients contained in the commercial fertilizers.

Among the six types of information the farmers sought, the new varieties and pesticides accounted for lower percentage. The information on new varieties sought by participant farmers accounted for $9.1 \%$ while that by non-participating farmers accounted for $7.3 \%$. For the case of pesticides and their applications, the information was sought by $13.4 \%$ for participating farmers while for non-participating farmers it was $6.5 \%$.

From the findings, it can be indicated that farmers were after suitable type of information taking into account the importance of land preparation, planting and weeding. Additionally, the results indicate that farmers were not conversant with the basic agriculture knowledge. According to Adhigurua et al. (2009), about $32 \%$ to 55\% of the farmers sought information on the seed in the cultivation sector, health care (26-54\%) in animal husbandry; and management and marketing $(8-46 \%)$ in fisheries. Regarding the adoption of information by farmers, the input dealers and other progressive farmers depicted greater influence mainly due to ease and convenient access to the sources.

Moreover, Spurk et al., (2013) found out that, there was a gap of what farmers intended to get and what they actually got. Agricultural information such as new varieties, planting methods or new crops were obtained by farmers, but more information was needed for instance, the information on markets, gaining more income and more basic knowledge.

\subsection{Farming Knowledge and Practices}

The farmers were asked about the corn farm preparation they practised. Most of the farmers prepared farms during the wet season. The preparation constituted $80.9 \%$ for participating and $72.5 \%$ for non-participating farmers. Further, the preparations of the farms for dry season are $19.1 \%$ and $27.5 \%$ for participating and non-participating farmers respectively. The results are presented in Figure 1. The results indicate that most of the farmers had knowledge about the season for farm preparation (both participant and non-participant farmers). 


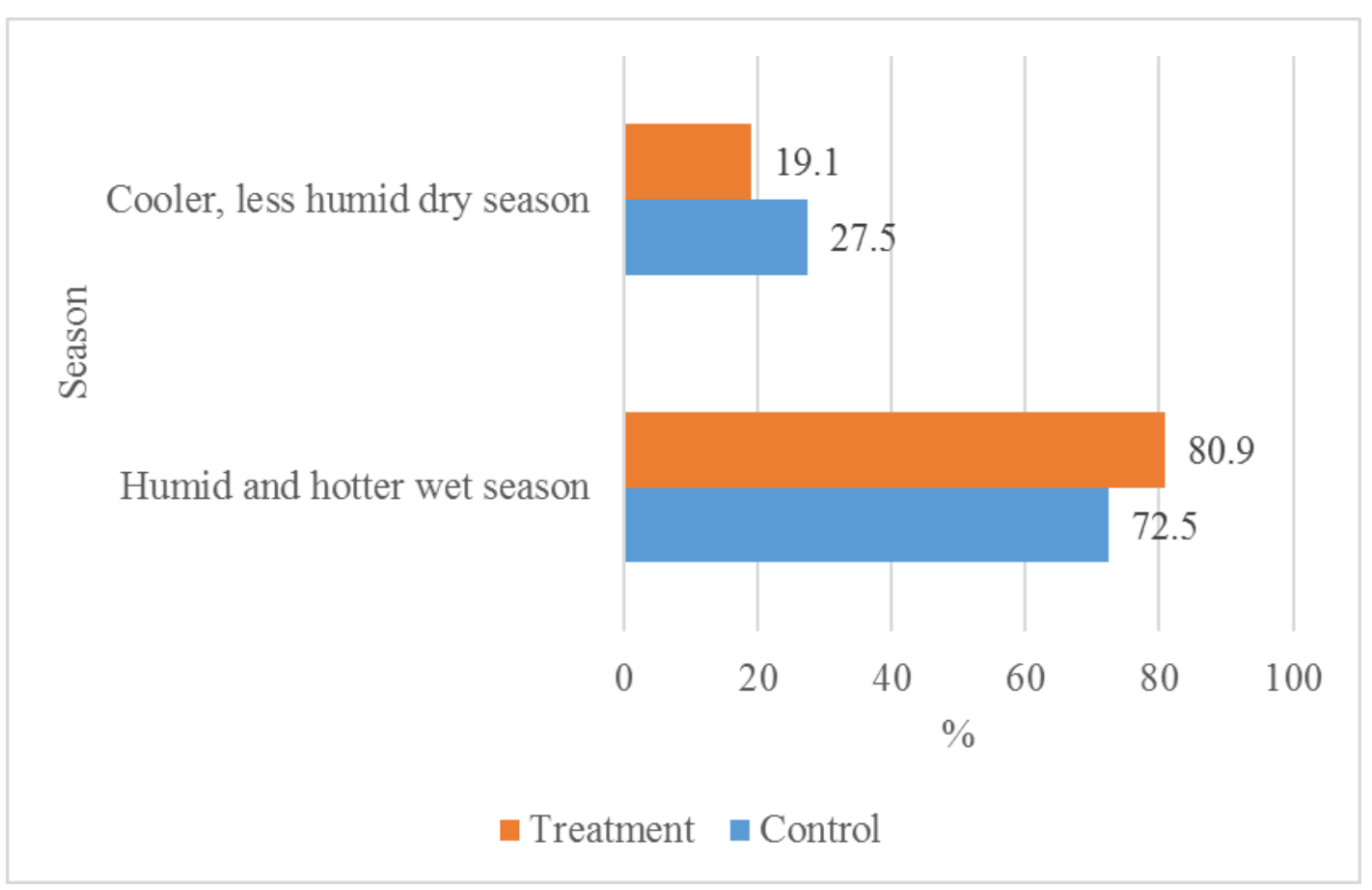

Figure 1. Season for Farm Preparation

Source: Field Data (2013)

In most regions of Tanzania, an onset of wet season is October. This implies that the farm preparation for most farmers starts in October. In their study on the adoption of corn production technologies in Southern Tanzania, Katinila et al. (1998) explain that the land preparation depends on the onset of the rains, which usually starts in late October. The land preparation is done during the wet season because the rain is used for land preparation due to the nature of cultivation. Most farmers prepare the land by holing using hand hoe and plough with few using tractors or power tiller.

When asked to state if it was important to know the types of soil before cultivation, 451 (87.9\%) of non-participating farmers said that it was important while the response was 335 (93.8\%) for participating farmers (See Table 5). The types of soil which include the soil texture and fertility have a big role in crops yield. The results show that the farmers were aware of the importance of type of soil in cultivation. The participating farmers have high rate of knowledge compared to non-participating ones.

Table 5. Importance of Type of Soil Information

\begin{tabular}{|c|c|c|c|}
\hline \multirow{3}{*}{ Group } & Response & Frequency & Percent \\
\hline \multirow{4}{*}{ Control } & Yes & 451 & 87.9 \\
\cline { 2 - 4 } & No & 62 & 12.1 \\
\cline { 2 - 4 } & Total & 513 & 100.0 \\
\cline { 2 - 4 } & Yes & 335 & 93.8 \\
\cline { 2 - 4 } & No & 22 & 6.2 \\
\cline { 2 - 4 } & Total & 357 & 100.0 \\
\hline
\end{tabular}

Source: Field Data (2013) 
The farmers were further asked to indicate the methods used to prepare the land. It was very important to explore this information taking into account that the land preparation is essential as it controls the weeds, recycles the plant nutrients and softens the soil. The land preparation is a major pre-requisite for increasing yield. The usage of different techniques in land preparation is presented in Table 6. The harrowing has high percentage of usage $(49.7 \%)$ as the land preparation method compared to other techniques by participating farmers. About $38.6 \%$ of non-participating farmers always used harrowing method to prepare the land.

Table 6. Land Preparation Techniques

\begin{tabular}{|c|c|c|c|c|c|}
\hline \multirow[b]{2}{*}{ Land preparation technique } & & \multicolumn{3}{|c|}{ Usage (\%) } & \multirow[b]{2}{*}{ Total } \\
\hline & & Never & Sometimes & Always & \\
\hline \multirow[b]{2}{*}{ Deep ploughing } & Control & 32.1 & 51.1 & 16.8 & 100 \\
\hline & Treatment & 33.5 & 36.9 & 29.6 & 100 \\
\hline \multirow[b]{2}{*}{ Harrowing } & Control & 16.2 & 45.1 & 38.6 & 100 \\
\hline & Treatment & 13.7 & 36.6 & 49.7 & 100 \\
\hline \multirow[b]{2}{*}{ Contouring } & Control & 37.3 & 37.3 & 25.3 & 100 \\
\hline & Treatment & 28.2 & 42.4 & 29.4 & 100 \\
\hline \multirow[b]{2}{*}{ Ridges } & Control & 32.0 & 31.4 & 36.5 & 100 \\
\hline & Treatment & 19.2 & 46.7 & 34.1 & 100 \\
\hline \multirow[b]{2}{*}{ Fertilizers and Manures } & Control & 23.2 & 50.6 & 26.2 & 100 \\
\hline & Treatment & 19.1 & 46.7 & 34.2 & 100 \\
\hline
\end{tabular}

Source: Field Data (2013)

The findings show that the used land preparation techniques were found to be positively related to production (see Akinboye et al., 2015 and Aikins et al., 2012). Thus, most of the farmers used proper land preparation method. Akinboye et al. (2015) finds out that ploughed, harrowed and ridged plots produced the longest vines compared to contouring. On their side, Aikins et al. (2012) conclude that considering the soil and weather conditions of the experiment, the optimum tillage practice for producing skposoe maize variety is disc harrowing only.

The farmers were tested with regard to their knowledge on nutrients deficiency to corn. It was important to assess the farmers' knowledge on soil fertility due to the fact that there is a decline of the soil fertility. The soil fertility has become one of the constraints on crop production as pointed out by Corbeels et al. (2000). The farmers were asked to identify which nutrient lacked when corn leaves turned yellow starting from the tips moving along to the middle of the leaves. Most of the farmers correctly identified that the lacked nutrient was nitrogen. About $90.3 \%$ of non-participating farmers identified it correctly while $84.6 \%$ of participating farmers identified the same (see Table 7). The participating farmers appeared to have low knowledge about the asked questions compared to non-participating farmers. This showed low impact of DASIP. Obour et al. (2015) explains that the farmers' knowledge on fertilizer use and management among the farmers and high market prices of mineral fertilizers constrained their usage. 
Table 7. Knowledge on Lack of Nutrients for Corn

\begin{tabular}{|l|c|c|c|c|}
\hline & \multicolumn{2}{|c|}{ Control } & \multicolumn{2}{c|}{ Treatment } \\
\hline \multicolumn{1}{|c|}{ Nutrient } & No. farmers & \% & No. farmers & \% \\
\hline Nitrogen & 215 & 90.3 & 209 & 84.6 \\
\hline Phosphate & 7 & 2.9 & 4 & 1.6 \\
\hline Potash & 12 & 5.0 & 27 & 10.9 \\
\hline Magnesium & 3 & 1.3 & 3 & 1.2 \\
\hline Sulphur & 1 & .4 & 4 & 1.6 \\
\hline Total & $\mathbf{2 3 8}$ & $\mathbf{1 0 0 . 0}$ & $\mathbf{2 4 7}$ & $\mathbf{1 0 0 . 0}$ \\
\hline
\end{tabular}

Source: Field Data (2013)

The study also wanted to know the application of pesticides among farmers taking into consideration its role in the crop production. The pesticide is one of the crop protection technologies and it is used to control pests such as insects, rodents, weeds, etc. The pesticides have effects on the crop production. Gianessi (2014) points out that Stemborers are major pests of maize in all African countries in the Southern Sahara. The damage caused by Stemborers is one of the main causes of low maize yields.

The study further finds out that the rate of not using pesticides to corn stood high at $58 \%$ for non-participating and $63.8 \%$ for participating farmers (see Table 8). Stadlinger et al. (2011) conducted a study on pesticide use among smallholder rice farmers in Tanzania and found out that the pesticide use was relatively low. Ngowi et al. (2007) conducted a study on pesticides use by smallholder farmers in vegetable production in Northern Tanzania and found out that more than $50 \%$ of the respondents applied the pesticides up to 5 times or more per cropping season depending on the crop. Shetty et al. (2010) reports that more than $50 \%$ of the respondents applied both single and cocktail pesticides to manage their crop pests. The reasons for the low usage of pesticide as revealed by this study could not be established since this was not part of the study objectives. It is recommended that the further study is required to establish the reasons for farmers not using pesticides.

Table 8. Application of Pesticides on Corn per Season

\begin{tabular}{|l|l|c|c|}
\hline & & Frequency & Percent \\
\hline \multirow{4}{*}{ Control } & Never & 294 & 58.0 \\
\cline { 2 - 4 } & Once & 164 & 32.3 \\
\cline { 2 - 4 } & Twice & 34 & 6.7 \\
\cline { 2 - 4 } & Thrice & 15 & 3.0 \\
\cline { 2 - 4 } & Total & 507 & 100.0 \\
\hline \multirow{5}{*}{ Treatment } & Never & 226 & 63.8 \\
\cline { 2 - 4 } & Once & 85 & 24.0 \\
\cline { 2 - 4 } & Twice & 39 & 11.0 \\
\cline { 2 - 4 } & Thrice & 4 & 1.1 \\
\cline { 2 - 4 } & Total & 354 & 100.0 \\
\hline
\end{tabular}

Source: Field Data (2013) 
Ngowi et al., (2002) finds out that the majority of extensionists knew that the pesticides could enter the human body but only a quarter perceived pesticides as a major problem in the community they served. The majority showed an awareness of potential health hazards of the different pesticides used in their service areas, but they did not recognize what pesticides had risk of poisoning.

\subsection{Relationship between Source of Information and Corn Yields}

This section examines the relationship between the source of information and corn yield. The matched data were used to run the odds ratio as the variables to be tested were nominal with only two possible responses (Yes/No). The relationship between the farmers and increase of corn yields were examined using odds ratio. The results are presented in Table 9.

Table 9. Relative Risk for Type of Famer and Corn Yield

\begin{tabular}{|l|c|c|c|}
\hline & & \multicolumn{2}{|c|}{$95 \%$ Confidence Interval } \\
\cline { 3 - 4 } & Value & Lower & Upper \\
\hline $\begin{array}{l}\text { Odds Ratio for experimental group } \\
\text { (Control/Treatment) }\end{array}$ & 8.724 & 5.655 & 13.460 \\
\hline For cohort has yield increased = No & 2.108 & 1.800 & 2.468 \\
\hline For cohort has yield increased = Yes & .242 & .176 & .332 \\
\hline N of valid cases & 502 & & \\
\hline
\end{tabular}

Source: Field Data (2013)

The odds ratio shows that non-participating farmers had 8.724 times the odds of corn yield not to increase compared to participating farmers. The confidence interval shows that the odds ratio is significant as the interval does not contain zero. The farmers who did not experience the increase of corn yield are 2.108 times as more likely to be non-participating farmers. This is to say that the corn yield for participating farmers is high compared to that for non-participating farmers. To test whether this difference is significant, the independent $t$ test was used. The Levene's test for equality of variances shows that the variability for participating and non-participating farmers was not significantly different as $p-v a l u e$ is 0.368 which is greater than 0.05 . Looking at $t$ test, the results show that mean corn yield for participating and non-participating farmers are not statistically different as $t_{0.05,323}=1.688, p=0.092$.

The insignificant difference of corn yield for participating and non-participating farmers could be caused by several factors such as insufficient rainfall because of unstable weather, non-usage of fertilizer, infertility of land, lack of quality seeds and disease. In Figure 2, it can be revealed that the participating farmers have slight excess of corn for selling (24.9\%) than non-participating farmers $(19.8 \%)$. The main corn usage for both types of farmers was identified to be food rather than income generation. 


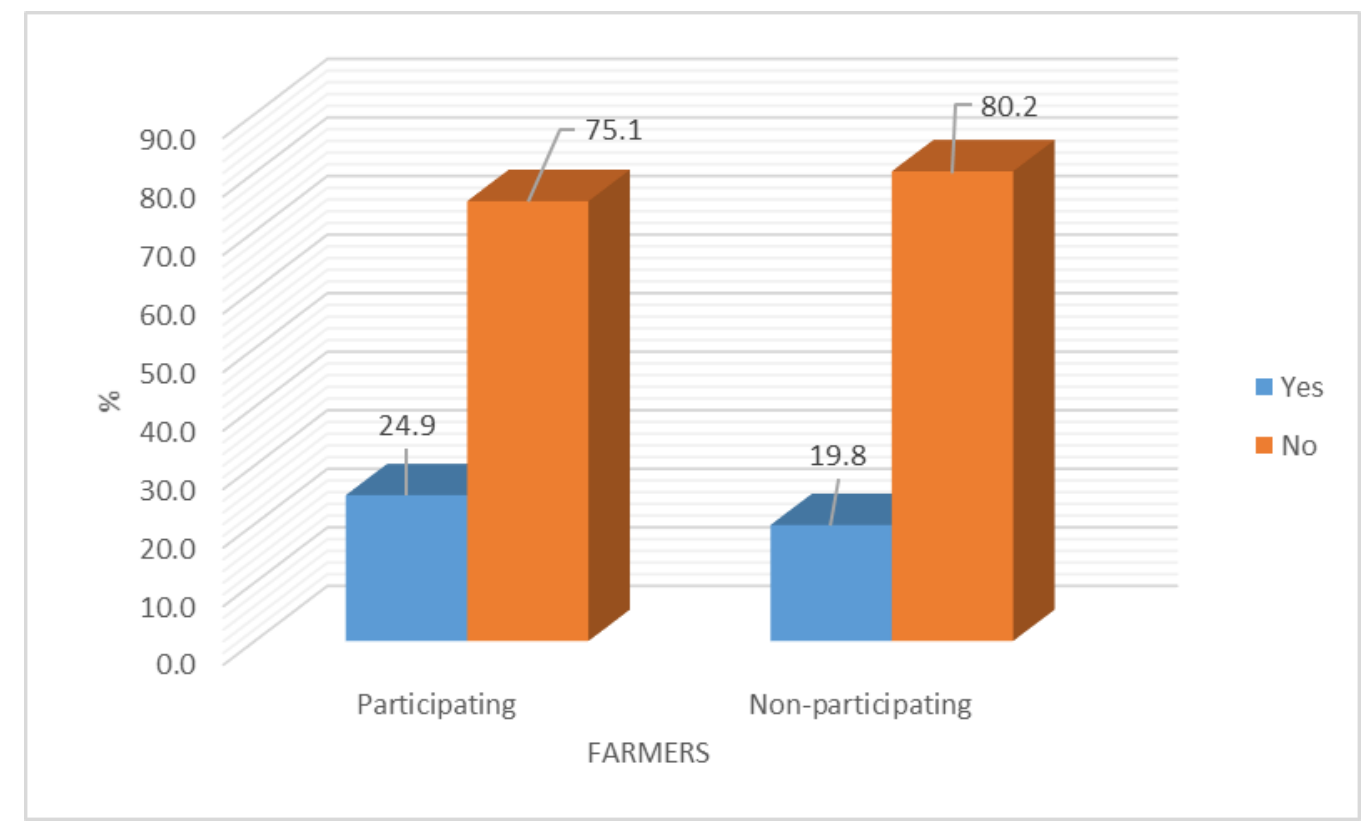

Figure 2. Excess of Corn for Selling

Source: Field Data (2013)

The farmers were asked to outline the reasons which influenced corn yield increase. The reasons mentioned included: education and training which constituted $38.3 \%$ of responses, application of better farming methods (17.7\%), and application of fertilizers (17.7\%). Also, more reasons were plenty rainfall $(14.2 \%)$, usage of quality seeds $(7.2 \%)$, increase of farm size $(2.8 \%)$ and seasonal sowing $(2.1 \%)$.

The study further assessed ten factors to find out if they could influence the increase of corn yield. The factors included: age, sex, marital status, participating in agriculture intervention, education, household size, corn land cultivation, distance to corn farm, usage of pesticides and usage of nutrients. The Logit model was used to examine the factors. The results show that among the ten factors examined, seven of them positively influence the corn yield (See Table 10).

From Table 10, it can be shown that the age is positively associated with corn yield as the odd ratio is 1 . The married farmers are positively associated with corn yield than non-married farmers. Also, the farmers participating in intervention have 8.767 odds of increasing corn production than non-participating farmers. Other factors which are positively associated with the increase of corn production are distance to corn farm, usage of the pesticides and nutrients.

In their study on climate change and maize production in Kaduna State - Nigeria, Ammani et al. (2012) find out that the annual rainfall has a significant and positive contribution to maize production in spite of the climate change. It is estimated that about $80 \%$ of the maize crop suffers periodic yield reduction due to drought stress. Their findings suggest that the climate change has changed the pattern of rainfall in such a way that the maize production is negatively affected. 
Table 10. Logit Analysis of Factors Influencing Corn Yield

\begin{tabular}{|l|c|c|c|c|c|c|}
\hline & B & S.E. & Wald & df & Sig. & Exp(B) \\
\hline Age & .000 & .010 & .001 & 1 & .981 & 1.000 \\
\hline Sex & -.172 & .232 & .550 & 1 & .458 & .842 \\
\hline Marital status & .343 & .374 & .842 & 1 & .359 & 1.410 \\
\hline Participating in intervention & 2.171 & .235 & 85.646 & 1 & .000 & 8.767 \\
\hline Education & -.003 & .038 & .006 & 1 & .938 & .997 \\
\hline Corn land cultivation & -.068 & .051 & 1.793 & 1 & .181 & .934 \\
\hline Distance_to_corn_Farm & .068 & .067 & 1.010 & 1 & .315 & 1.070 \\
\hline Usage of pesticides & .630 & .255 & 6.101 & 1 & .014 & 1.877 \\
\hline Usage of nutrients & .868 & .255 & 11.547 & 1 & .001 & 2.382 \\
\hline Constant & -2.454 & .686 & 12.794 & 1 & .000 & .086 \\
\hline
\end{tabular}

Source: Field Data (2013)

Kimeli (2013) also finds out that there is a relationship between the climatic conditions (rainfall) and the quantity of maize produced. Other factors which were found to affect maize production are soil moisture content and recharge, potential evapotranspiration, soil type, planting seasons, cropping methods, level of temperature, fertilizer, labour and seeds (Kimeli, 2013).

\subsection{Conclusions}

From the findings, it can be concluded that the effects of DASIP on participating farmers is very little as they resemble non-participating farmers in terms of knowledge and farming practices. The sources of agricultural information for both participating and non-participating farmers were from own experience of farmers. The participating farmers had little knowledge about lack of corn nutrients compared to non-participating farmers. Additionally, the usage of corn pesticides for participating farmers was low compared to non-participating farmers. The knowledge imparted to farmers in DASIP did not make significant increase in terms of corn yield compared to non-participating farmers. Based on the findings, the study recommends the followings:

(i) The effectiveness of agriculture extension also depends on seriousness of farmers. Basing on this fact, the study recommends that the farmers should consider uplifting their level of adoption of agricultural technologies.

(ii) In order to increase the yield, the farmers should be advised to use pesticides as required, taking into consideration the role of pesticides in crop production.

(iii) Since most of the farmers (both participating and non-participating farmers) access information from their own experience, it is suggested that, for easy access and effective utilization of agricultural information, the centers should be established in rural areas.

(iv) For the effectiveness of the agricultural extension, the Ministry of Agriculture, Food Security and Cooperatives should ensure that the extensions are running smoothly by 
providing technical and financial commitment to improve performance of extension officers.

\section{References}

Abosede, S. A., Alabi, A. O., and Oluyemisi, F. B. (2014), "Farmers Information Literacy and Awareness towards Agricultural Produce and Food Security: FADAMA III programs in Osun state Nigeria", [http://library.ifla.org/1001/1/140-sokoya-en.pdf].

Adhigurua, P., Birthalb, P. S., \& Kumara, B. G. (2009). "Strengthening Pluralistic Agricultural Information Delivery Systems in India", Agricultural Economics Research Review, 22, 71-79.

Aikins, S. H. M., Afuakwa, J. J., \& Owusu-Akuoko, O. (2012). "Effect of Four Different Tillage Practices on Maize Performance under Rainfed Conditions", Agriculture and Biology Journal of North America, 3(1), 25-30. http://dx.doi.org/10.5251/abjn a.2012.3.1.25.30.

Akinboye O. E., Oyekale K. O., \& Aiyelari E. A. (2015). "Effects of Land Preparation Methods on the Growth and Yield of Sweet Potato (Ipomoea Batatas LAM)", International Journal of Research in Agriculture and Forestry, 2(1), 33-39.

Akowuah, P., Sarkodie-Addo, J., \& Boa, K. (2012). "Effect of Some Agronomic Practices to Increase Maize Yield in Ghana", Journal of Science and Technology, 32(2), 1-8. http://dx.doi.org/10.4314/just.v32i2.1.

Ammani, A. A., Ja'afaru, A. K., Aliyu, J. A., \& Arab, A. I. (2012). "Climate Change and Maize Production: Empirical Evidence from Kaduna State, Nigeria”, Journal of Agricultural Extension, 16(1), 1 - 8. http://dx.doi.org/10.4314/jae.v16i1.1.

Bello, M., \& Obinne, C. P. O. (2012). "Problems and Prospects of Agricultural Information Sources Utilization by Small Scale Farmers: A Case from Nasarawa State of Nigeria", Journal of Communication, 3(2), 91-98.

Corbeels, M., Shiferaw, A., \& Haile, M. (2000). "Farmers' Knowledge of Soil Fertility and Local Management Strategies in Tigray, Ethiopia", Discussion Paper, Managing Africa's Soils, 10.

Csótó, M. (2010). "Information Flow in Agriculture - through New Channels for Improved Effectiveness", Journal of Agricultural Informatics, 1(2), 25-34. http://dx.doi.org/ 10.17700/jai.2010.1.2.17.

Daudu, S., Chado, S. S. \& Igbashal, A. A. (2009). "Agricultural Information Sources Utilized By Farmers in Benue State, Nigeria”, Production Agriculture and Technology Journal, 5(1), $39-48$.

Davis, K., Nkonya, E., Kato, E., Mekonnen, D. A., Odendo, M., \& Miiro, R. (2010). Impact of Farmer Field Schools on Agricultural Productivity and Poverty in East Africa, IFPRI Discussion Paper 00992, International Food Policy Research Institute.

Feder, G. Murgai, R., \& Quizon J. B. (2004), "Sending Farmers Back to School: The Impact 
of Farmer Field Schools in Indonesia”, Policy Research Working Paper, 3022.

Fliert, E.V. D., \& Van de Fliert, E. (1993). "Integrated Pest Management: Farmer Field Schools Generate Sustainable Practices”, Agricultural University Wageningen Papers, 34(3), 93-103.

Gianessi, L. (2014). Importance of Pesticides for Growing Maize in Sub-Saharan Africa, International Pesticide Benefits Case Study, 104.

Godtland, E. M., Sadoulet, E., De Janvry, A., Murgai, R., \& Ortiz, O. (2004). "Impact of Farmer Field Schools on Knowledge and Productivity, A Study of Potato Farmers in the Peruvian Andes", Economic Development and Cultural Change, 53(1), 63-92. http://dx.doi.org/10.1086/423253.

Habib, M., Zafarullah, M., Iqbal, M., Nawab, K., \& Ali, S. (2007). "Effect of Farmer Field Schools on Sugar Cane Productivity in Malakand Agency", Sarhad Journal of Agriculture, 23(4), $1133-1137$.

Katinila, N., Verkuijl, H., Mwangi, W., Anandajayasekeram, P., \& Moshi, A. J. (1998). "Adoption of Maize Production Technologies in Southern Tanzania. International Maize and Wheat Improvement Center (CIMMYT)", [http://www.tanzaniagateway.org/docs/maize_production_technologies_in_southern_tanzania .pdf].

Kimeli C. M. (2013). Determining Factors That Affect Maize Production in Turbo Constituency, Kenya, Master Thesis, University of Nairobi.

Mbilinyi, A., Ole Saibul, G., \& Kazi, V. (2013). "Impact of Climate Change to Small Scale Farmers: Voices of Farmers in Village Communities in Tanzania", Economic and Social Research Foundation, Discussion Paper, 36.

Mtega, W. P., \& Ronald, B. (2013). "The State of Rural Information and Communication Services in Tanzania: A Meta-Analysis", International Journal of Information and Communication Technology Research, 3(2) 2: 64 - 73.

Naveed, M. A., \& Anwar, M. A. (2013). “Agricultural Information Needs of Pakistani Farmers", Malaysian Journal of Library and Information Science, 18(3), 13-23.

Naveed, M. A., Anwar, M. A., \& Bano, S. (2012). "Information Seeking by Pakistani farmers: A review of published research", Pakistan Journal of Library \& Information Science, 13.

Ngowi, A. V., Maeda, D. N., \& Partanen, T. J. (2002). "Knowledge, Attitudes and Practices (KAP) among Agricultural Extension Workers Concerning the Reduction of the Adverse Impact of Pesticides in Agricultural Areas in Tanzania", Medicina del Lavoro, 93(4), 338-46.

Ngowi, A. V., Mbise, T. J., Ijani, A. S. M., London, L., \& Ajayi, O. C. (2007). "Pesticides Use by Smallholder Farmers in Vegetable Production in Northern Tanzania", Crop Prot, 26(11), 1617-1624. http://dx.doi.org/ 10.1016/j.cropro.2007.01.008.

Obour, P. B., Dadzie, F. A., Kristensen, H. L., Rubæk, G. H., Kjeldsen, C., \& Saba, C. K. S. 
(2015). “Assessment of Farmers' Knowledge on Fertilizer Usage for Peri-Urban Vegetable Production in the Sunyani Municipality, Ghana", Resources, Conservation and Recycling, 103, 77-84. http://dx.doi.org/ 10.1016/j.resconrec.2015.07.018.

Opara, U. N. (2008). "Agricultural Information Sources Used by Farmers in Imo State, Nigeria”, Information Development, 24(4), 289-295. http://dx.doi.org/ $10.1177 / 0266666908098073$.

Praneetvatakul, S., \& H. Waibel. 2006. Impact Assessment of Farmer Field School using a Multi-Period Panel Data Model. Paper presented at International Association of Agricultural Economics conference, 12-18 August 2006, Gold Coast, Australia.

Quizon, J., Feder, G., \& Murgai, R. (2001). Fiscal Sustainability of Agricultural Extension: The Case of the Farmer Field School Approach, Journal on International Agricultural and Extension Education, 8, 13-24. http://dx.doi.org/10.5191/jiaee.2001.08102.

Rola, A. C., Jamias, S. B., \& Quizon, J. B. (2002). Do Farmer Field School Graduates Retain and Share What they Learn: An Investigation in Iloilo, Philippines, Journal of International Agricultural and Extension Education, 9, 65-76. http://dx.doi.org/10.5191/jiaee.2002.09108

Sher, A. (2013). Effect of Agronomic Practices on the Yield and Quality of Rainfed Sorghum Forage, $\mathrm{PhD}$ thesis, Arid Agriculture University, Rawalpindi.

Shetty, P. K., Murugan, M., Hiremath, M. B., \& Sreeja, K. G. (2010). "Farmers' Education and Perception on Pesticide Use and Crop Economies in Indian Agriculture", Journal of Experimental Sciences, 1(1), 03-08.

Spurk, C., Schanne, M., Mak'Ochieng, M., \& Ugangu, W. (2013). Kenyan Farmers and their Assessment of Information on Agricultural Innovation, Unpublished report, Multimedia University College of Kenya and Inandtute of Applied Media Studies.

Stadlinger, N., Mmochi, A. J., Dobo, S., Gyllbäck, E., \& Kumblad, L. (2011). "Pesticide Use among Smallholder Rice Farmers in Tanzania", Environment, Development and Sustainability, 13(1), 641-656. http://dx.doi.org/10.1007/s10668-010-9281-5.

Yamazaki, S., \& Resosudarmo, B. P. (2007). "Does Sending Farmers Back to School Have an Impact? A Spatial Econometric Approach”, Working Paper, 3.

\section{Copyright Disclaimer}

Copyright for this article is retained by the author(s), with first publication rights granted to the journal.

This is an open-access article distributed under the terms and conditions of the Creative Commons Attribution license (http://creativecommons.org/licenses/by/3.0/). 